\title{
PERAN ORGANISASI SAYAP PARTAI POLITIK (OSP) DALAM MENCEGAH KEMEROSOTAN KEANGGOTAAN PARTAI POLITIK DI INDONESIA
}

\author{
Yenny Febrianty \\ Dosen Fakultas Hukum Universitas Pakuan, Bogor dan Mahasiswa S3 Progran Doktor \\ Ilmu Hukum FH Universitas Dipenogoro, Semarang \\ Jamaludin Ghafur \\ Dosen Hukum Tata Negara Fakultas Hukum Universitas Islam Indonesia, dan Mahasiswa \\ S3 Progran Doktor Ilmu Hukum FH Universitas Indonesia, Jakarta. \\ Ariyanto \\ Dosen Fakultas Hukum Yayasan Pendidikan Islam (Yapis) Papua, dan Mahasiswa S3 \\ Progran Doktor Ilmu Hukum FH Universitas Dipenogoro, Semarang
}

\begin{abstract}
Abstrak
Partai politik (parpol) saat ini menyandang status dualisme. Di satu sisi ia dipercaya sebagai fitur penting dalam demokrasi perwakilan, namun pada sisi yang lain, parpol tidak cukup dipercaya untuk dapat melaksanakan perannya secara baik yaitu sebagai sarana kelembagaan yang utama untuk menjembatani hubungan (kepentingan) antara masyarakat dengan pemerintah. Akibatnya, dalam banyak survey didapat dua kesimpulan yang saling bertolak belakang yaitu: eksistensi parpol dianggap penting, tetapi mayoritas masyarakat tidak begitu yakin parpol peduli dengan aspirasi masyarakat. Sehingga, masyarakat tidak begitu tertarik untuk terlibat dalam aktifitas politik secara umum, dan enggan menjadi anggota parpol secara khusus. Hal ini dapat dilihat dari terus merorotnya jumlah anggota parpol dari tahun ke tahun. Bahkan, jika dibandingkan dengan jumlah pemilih dalam pemilu 2019, hanya 4,9 $\%$ saja warga masyarakat Indonesia yang menjadi anggota parpol. Padahal, keberadaan anggota parpol sangat penting yaitu sebagai salah satu sumber dalam membangun kepercayaan masyarakat terhadap parpol dan sistem politik. Oleh sebab itu, penurunan keanggotaan paprol merupakan sinyal akan kemerosotan kepecayaan masyarakat pada parpol dan sistem politik secara umum. Oleh sebab itu, parpol perlu memikirkan startegi baru untuk menarik minat masyarakat untuk berpartisipasi dalam organisasi parpol. Salah satu instrumen yang dapat digunakan oleh parpol untuk meningkatkan kembali antusiasme masyarakat pada parpol adalah melalui organisasi sayap parpol (onderbouw)) yang keberadaannya secara hukum telah diakui dalam UU Partai Politik namun belum cukup terberdayakan.
\end{abstract}

Kata Kunci: Organisasi Sayap Partai Politik (OSP), Partai Politik, dan Kemerosotan Keanggotaan Partai Politik

Abstract

Political parties currently carry the status of dualism. On the one hand it is believed to be an important feature in representative democracy, but on the other hand, political parties are not sufficiently trusted to be able to carry out their roles well as the main institutional means to bridge the relationship between the community and the government. As a result, in many surveys there were two conflicting conclusions: the existence of political parties was considered important, but the majority of the people were not so sure that political parties cared about what people think. Therefore, people are not very interested in being involved in political activities in general, and are reluctant to become members of political parties specifically. This can be seen from the continued decline in the number of political party 
members from year to year. Moreover, compared to the number of voters in the 2019 election, only $4.9 \%$ of Indonesian citizens became members of political parties. Whereas, the existence of political party members is very important as one of the sources in building public trust in political parties and the political system. The decline in political party membership is a signal of a decline in public trust in political parties and the political system in general. Therefore, political parties need to think of new strategies to attract the public to participate in political party organizations. One of the instruments that can be used by political parties to revive people's enthusiasm for political parties is through the political party branch organization (onderbouw) whose existence has been legally recognized in the Law on Political Parties but has not been sufficiently empowered.

Keywords: Political Party Branch Organization (onderbouw), Political Parties, and Declining Membership of Political Parties

\section{A. Pendahuluan}

Siapapun tidak ada yang meragukan peran dan fungsi sentral parpol dalam sistem demokrasi perwakilan (representative democracy). Richards Katz berpendapat, "modern democracy is party democracy". ${ }^{1}$ Sementara itu, dengan mengutip beberapa pendapat pakar, Russell J. Dalton dan Steven A. Weldon secara tegas menulis dalam artikelnya yang berjudul "Public Images of Political Parties: A Necessary Evil?", diterbitkan dalam jurnal West European Politics, sebagai berikut:

Perhaps no institution is so closely identified with the process of representative democracy as are political parties. The renowned political scientist E.E. Schattschneider (1942: 1) penned the oft-cited conclusion that 'modern democracy is unthinkable save in terms of political parties'. Similarly, James Bryce (1921: 119) stated 'parties are inevitable. No one has shown how representative government could be worked without them'. More recently, Giovani Sartori wrote, 'citizens in Western democracies are represented through and by parties. This is inevitable' (Sartori 1968: 471). ${ }^{2}$

Mungkin tidak ada lembaga yang begitu erat diidentifikasi dengan proses demokrasi perwakilan seperti halnya partai politik. Ilmuwan politik terkenal E.E. Schattschneider (1942: 1) menulis kesimpulan yang sering dikutip bahwa "demokrasi modern tidak terpikirkan kecuali dalam hal partai politik". Demikian pula, James Bryce (1921: 119) menyatakan 'partai politik adalah sebuah keniscayaan. Tidak ada yang menunjukkan bagaimana pemerintah perwakilan dapat bekerja tanpa partai politik'. Baru-baru ini, Giovani Sartori menulis, 'warga negara di negara demokrasi Barat diwakili melalui dan oleh partai-partai. Hal ini tidak bisa dihindari '(Sartori 1968: 471).

Namun demikian, harapan dan imaji tentang penting dan sentralnya peran parpol dalam sistem demokrasi tidak berbanding lurus dengan kinerja baik parpol dalam menciptakan demokrasi yang berkualitas. Bila secara teori parpol dianggap sebagai pilar penting tegaknya demokrasi perwakilan, dalam tataran praktik ketatanegaraan, keberadaan parpol justru dipandang sinis atau bahkan tidak lagi dipercaya oleh sebagian besar publik.

Hasil survei opini publik tentang bagaimana publik kontemporer memandang partai politik yang dilakukan oleh Comparative Study of Electoral Systems (CSES) menyajikan

${ }^{1}$ Richard S. Katz, A Theory of Parties and Electoral System, The Johns Hopkins University Press, Baltimore, 1980, hlm. 1

${ }^{2}$ Russell J. Dalton and Steven A. Weldon, Public Images of Political Parties: A Necessary Evil?, West European Politics, Vol. 28, No. 5, 931 - 951, November 2005, hlm. 931 
pendapat tentang dua bahan penting dari perdebatan saat ini tentang citra partai yang tergambar dari jawaban atas dua pertanyaan penting: Pertama, apakah partai-partai politik diperlukan dan penting bagi demokrasi, dan Kedua, apakah partai politik peduli terhadap apa yang dipikirkan atau menjadi kebutuhan masyarakat. Jawaban atas kedua pertanyaan ini mencerminkan paradoks pendapat saat ini. Ketika ditanya apakah partai politik penting, sekitar tiga perempat masyarakat di 13 negara demokrasi ini menyatakan setuju. Namun, publik kontemporer secara bersamaan skeptis tentang apakah partai peduli dengan kepentingan masyarakat. 80 persen orang Swedia mengatakan partai diperlukan untuk membuat sistem politik berfungsi, hanya 23 persen percaya bahwa partai peduli dengan aspirasi masyarakat. Demikian pula, 80 persen orang Jerman menganggap partai itu perlu, tetapi hanya 18 persen masyarakat yang percaya bahwa partai peduli terhadap kepentingan publik. $^{3}$

Penjelasan lebih rinci tentang bertolak belakangnya pendapat masyarakat Eropa terhadap arti pentingnya parpol dalam negara demokrasi dan seberapa peduli parpol menurut publik terhadap kepentingan masyarakat, disajikan dalam tabel 1 berikut:

Tabel 1: Citra Partai Politik di Mata Publik

PUBLIC IMAGES OF POLITICAL PARTIES

\begin{tabular}{lcc}
\hline & $\begin{array}{c}\text { Political Parties } \\
\text { are Necessary }\end{array}$ & $\begin{array}{c}\text { Political Parties Care what } \\
\text { People Think }\end{array}$ \\
\hline Australia & 71 & 23 \\
Britain & 77 & 34 \\
Canada & 65 & 23 \\
Denmark & 88 & 30 \\
Germany & 80 & 18 \\
Japan & 65 & 21 \\
Netherlands & 90 & 43 \\
New Zealand & 71 & 26 \\
Norway & 89 & 39 \\
Spain & 83 & 39 \\
Sweden & 80 & 23 \\
Switzerland & 78 & 39 \\
USA & 56 & 38 \\
Average & $\mathbf{7 6}$ & $\mathbf{3 0}$ \\
\hline
\end{tabular}

Note: Table entries are the percentage agreeing with each statement.

Dalam konteks Indonesia, berbagai jajak pendapat publik yang dilakukan Lembaga Survei Indonesia (LSI) dan Saiful Mujani Research and Consulting (SMRC) sejak 2004, secara konsisten juga ditemukan fakta bahwa masyarakat cenderung berpandangan negatif terhadap institusi parpol dan para politisi. Karena para politisilah yang mengisi lembaga DPR, persepsi terhadap DPR pun secara konsisten cenderung negatif. Menurut LSI, di awal tahun 2015, tingkat kepercayaan masyarakat kepada parpol dan DPR berada di kisaran 50 persen. Ini angka terendah dibandingkan dengan tingkat kepercayaan masyarakat terhadap Presiden sebesar 83 persen, KPK 81 persen, dan TNI 83 persen. Angka ini lebih rendah lagi pada 2014, setelah pemilu legislatif dan pemilu presiden. Pada Oktober 2014, kepercayaan terhadap parpol dan DPR ada di kisaran 40 persen. ${ }^{4}$

Fenomena ini menurut Ingrid van Biezen telah menyebabkan mayoritas literatur ilmiah tentang partai-partai politik dalam demokrasi modern dibangun di sekitar dua

\footnotetext{
${ }^{3}$ Ibid, hlm. 933-934

${ }^{4}$ Djayadi Hanan, Parpol dan Persepsi Publik, Kompas, Sabtu, 11 April 2015.
} 
proposisi yang tampaknya bertentangan. Yang pertama adalah bahwa, sebagaimana pernyataan terkenal oleh Schattschneider lebih dari setengah abad yang lalu, "demokrasi modern tidak terpikirkan kecuali dengan partai politik". Yang kedua, sebagaimana pendapat Schmitter bahwa, "partai politik tidak (lagi menjalankan fungsi) seperti dulu". 5

Posisi ambigu partai-partai dalam demokrasi kontemporer sebagian merupakan produk dari ketegangan antara keberlanjutan atau bahkan peningkatan sentralitas partaipartai politik sebagai lembaga-lembaga utama demokrasi modern dan kegagalan mereka yang meningkat dalam melakukan banyak fungsi yang dipandang penting untuk kinerja yang sehat bagi demokrasi. Sebagaimana diketahui, keberadaan parpol begitu kuat berakar dalam demokrasi Barat yang telah mapan, sampai-sampai sulit bahkan untuk membayangkan pemerintahan demokratis tanpa kehadiran partai politik. Namun di pihak lain, parpol juga dianggap gagal melakukan banyak fungsi yang secara tradisional ditugaskan kepada mereka seperti fungsi representasi. Tegasnya, kinerja parpol telah banyak mengecewakan masyarakat secara luas.

Implikasi dari menurunnya kepercayaan publik terhadap parpol adalah terdegradasinya jumlah ketertarikan orang untuk bergabung menjadi anggota partai politik. Hal ini dibuktikan dari kecilnya rasio antara jumlah anggota parpol dengan jumlah pemilih dalam pemilu 2019. Jumlah keseluruhan anggota parpol peserta pemilu 2019 adalah 9.537.648 sementara jumlah total Pemilih Pemilu 2019 adalah 192.866.254 pemilih dengan rincian 190.779.969 pemilih di dalam negeri dan 2.086.285 pemilih di luar negeri. ${ }^{6}$ Jadi, jumlah anggota parpol hanya 4,9\% persen dari jumlah pemilih. Bahkan, Partai Republika Nusantara hanya memiliki 84 orang anggota.

${ }^{5}$ Ingrid van Biezen, The Place of Parties in Contemporary Democracies, West European Politics, volume 26 , issue 3,2003 , hlm. 174

6 Jumlah Pemilih Pemilu 2019 Bertambah Jadi 192.866.254", https://nasional.kompas.com/read/2019/04/08/21501411/jumlah-pemilih-pemilu-2019-bertambah-jadi192866254, diakses tanggal 14 April 2019 
Tabel 2: Jumlah Anggota Partai Politik pada Pemilu 2019.7

\begin{tabular}{|c|c|c|c|c|c|c|c|c|}
\hline \multirow{2}{*}{ No. } & \multirow{2}{*}{ Nama Parpol } & \multirow{2}{*}{ Akronim } & \multirow{2}{*}{$\begin{array}{c}\begin{array}{c}\text { Keterwakilan } \\
\text { Perempuan (\%) }\end{array} \\
\text { Pusat }\end{array}$} & \multirow{2}{*}{$\begin{array}{c}\text { Sebaran } \\
\text { Pengurus (\%) } \\
\begin{array}{c}\text { Min. } 100 \% \text { di } \\
\text { Provinsi }\end{array}\end{array}$} & \multicolumn{3}{|c|}{ Jumlah Kepengurusan dan Kantor } & \multirow{2}{*}{$\begin{array}{c}\text { Jumlah } \\
\text { Keanggotaan }\end{array}$} \\
\hline & & & & & Provinsi & $\begin{array}{l}\text { Kabupaten/ } \\
\text { Kota }\end{array}$ & Kecamatan & \\
\hline 1 & INDONESIA KERJA & PIKA & $40.00(2 / 5)$ & $100.00(34 / 34)$ & 34 & 445 & 2.694 & 539.363 \\
\hline 2 & $\begin{array}{l}\text { PARTAI NASIONAL INDONESIA } \\
\text { MARHAENISME }\end{array}$ & PNIM & $28.57(2 / 7)$ & $5.00(2 / 34)$ & 2 & 12 & 0 & 1.177 \\
\hline 3 & PARTAI AMANAT NASIONAL & PAN & $32.46(25 / m)$ & $100.00(34 / 34)$ & 34 & 514 & 5.500 & 496.623 \\
\hline 4 & PARTAI BERKARYA & BERKARYA & $36.36(4 / 11)$ & $100.00(34 / 34)$ & 34 & 486 & 5.328 & 409.022 \\
\hline 5 & PARTAI BHINNEKA INDONESIA & PBI & 33.33 (1/3) & $100.00(34 / 34)$ & 34 & 444 & 1.324 & 83.563 \\
\hline 6 & PARTAI BULAN BINTANG & PBB & $3437(11 / 32)$ & $100.00(34 / 34)$ & 34 & 499 & 4.493 & 373.063 \\
\hline 7 & $\begin{array}{l}\text { PARTAI DEMOKRASI INDONESIA } \\
\text { PERJUANGAN }\end{array}$ & PDI PERJUANGAN & $38.46(15 / 39)$ & $100.00(34 / 34)$ & 34 & 514 & 6.110 & 339.224 \\
\hline 8 & PARTAI DEMOKRAT & PD & 31.49 (40/127) & $100.00(34 / 34)$ & 34 & 514 & 6.845 & 412.397 \\
\hline 9 & PARTAI GERAKAN INDONESIA RAYA & GERINDRA & 38.78 (121/312) & $100.00(34 / 34)$ & 34 & 514 & 6.972 & 468.519 \\
\hline 10 & $\begin{array}{l}\text { PARTAI GERAKAN PERUBAHAN } \\
\text { INDONESIA }\end{array}$ & Partai Garuda & $36.36(4 / 11)$ & $100.00(34 / 34)$ & 34 & 509 & 4.754 & 693.191 \\
\hline 11 & PARTAI GOLONGAN KARYA & Partai GOLKAR & 31.41 (82/261) & $100.00(34 / 34)$ & 34 & 514 & 7.015 & 675.088 \\
\hline 12 & PARTAI HATI NURANI RAKYAT & HANURA & $33.33(49 / 147)$ & $100.00(34 / 34)$ & 34 & 513 & 5.768 & 828.225 \\
\hline 13 & PARTAI ISLAM DAMAI AMAN & IDAMAN & $33.33(1 / 3)$ & $100.00(34 / 34)$ & 34 & 432 & 1.400 & 266.074 \\
\hline 14 & $\begin{array}{l}\text { PARTAI KEADILAN DAN PERSATUAN } \\
\text { INDONESIA }\end{array}$ & PKP INDONESIA & $41.37(12229)$ & $100.00(34 / 34)$ & 34 & 471 & 4.930 & 460.822 \\
\hline 15 & PARTAI KEADILAN SEJAHTERA & PKS & $32.89(25 / 76)$ & $100.00(34 / 34)$ & 34 & 477 & 5.069 & 300.158 \\
\hline 16 & PARTAI KEBANGKITAN BANGSA & PKB & $38.77(19 / 49)$ & $100.00(34 / 34)$ & 34 & 497 & 5.282 & 375.254 \\
\hline 17 & PARTAI NASDEM & Nasional Demokrat & $36.00(9 / 25)$ & $100.00(34 / 34)$ & 34 & 514 & 7.162 & 402.769 \\
\hline 18 & PARTAI PEMERSATU BANGSA & PPB & $0.00(0 / 3)$ & $91.00(31 / 34)$ & 31 & 449 & 180 & 5.557 \\
\hline 19 & $\begin{array}{l}\text { PARTAI PENGUSAHA DAN PEKERJA } \\
\text { INDONESIA }\end{array}$ & PPPI & $36.84(7 / 19)$ & $100.00(34 / 34)$ & 34 & 101 & 236 & 209.348 \\
\hline 20 & $\begin{array}{l}\text { PARTAI PERSATUAN } \\
\text { PEMBANGUNAN }\end{array}$ & PPP & 3239 (23/7) & $100.00(34 / 34)$ & 34 & 496 & 5.653 & 390.982 \\
\hline 21 & PARTAI RAKYAT & Rakyat & $33.33(3 / 9)$ & $100.00(34 / 34)$ & 34 & 272 & 124 & 352.961 \\
\hline 22 & PARTAI REFORMASI & PR & $0.00(0 / 3)$ & $0.00(0 / 34)$ & 0 & 0 & 0 & 131 \\
\hline 23 & PARTAI REPUBLIK & REPUBLIK & $33.33(1 / 3)$ & $100.00(34 / 34)$ & 34 & 487 & 3.647 & 289.652 \\
\hline 24 & PARTAI REPUBLIKA NUSANTARA & Republikan & $0.00(0 / 0)$ & $0.00(0 / 34)$ & 0 & 0 & 0 & 84 \\
\hline 25 & PARTAI SOLIDARITAS INDONESIA & PSI & $66.66(6 / 9)$ & $100.00(34 / 34)$ & 34 & 429 & 3.914 & 332.172 \\
\hline 26 & PARTAI SWARA RAKYAT INDONESIA & PARSINDO & $40.00(2 / 5)$ & $100.00(34 / 34)$ & 34 & 423 & 3.071 & 202.370 \\
\hline 27 & PERSATUAN INDONESIA & PERINDO & $32.00(8 / 25)$ & $100.00(34 / 34)$ & 34 & 511 & 7.023 & 629.859 \\
\hline
\end{tabular}

Hal lainnya yang dapat dijadikan bukti betapa tidak simpatiknya masyarakat terhadap parpol di Indonesia adalah hasil survei Indikator Politik Indonesia yang menunjukkan, pada pemilu 2014, hanya 14,3 persen responden yang mengaku dekat dengan salah satu parpol. Sebaliknya, sebanyak 85,5 persen responden mengaku tidak dekat dengan parpol manapun dan 0,2 persen tidak menjawab. Jadi, hampir 90 persen yang swing voters. Dari 14,3 persen responden yang mengaku dekat dengan parpol, dirinci lagi seberapa dekat mereka. Sebanyak 26 persen mengaku sangat dekat, 51 persen cukup dekat, 19 persen sedikit dekat dan 4 persen tidak menjawab. Angka kedekatan publik terhadap parpol itu terus merosot dari waktu ke

${ }^{7}$ https://infopemilu.kpu.go.id/pileg2019/verpol/parpol, diakses tanggal 14 April 2019 
waktu karena hasil Survei Lembaga Survei Indonesia dan SMRC menyimpulkan kedekatan publik dengan parpol di Mei 2011 masih di angka 21 persen. ${ }^{8}$

Jika ketidakpercayaan ini berkembang semakin meluas, bukan tidak mungkin akan berkonsekuensi pada kehancuran sistem demokrasi itu sendiri. Sebagaimana disinyalir oleh Firman Noor, munculnya kekuatan fasisme di Eropa Barat, jika di tilik lebih saksama, justru berawal dari kegagalan partai-partai politik dalam menjalankan tugas dan fungsinya. Alihalih menjadi sebuah kekuatan kunci pemerintahan yang didukung rakyat, partai politik menjelang kebangkitan sebuah rezim fasis dipandang justru sebagai penyebab banyak persoalan yang memunculkan rasa frustasi rakyat. ${ }^{9}$ Dampak paling serius atas kinerja negatif partai adalah potensi munculnya sikap sentimen anti-partai. Sentimen anti partai merupakan sikap minor warga negara terhadap partai politik menyangkut eksistensi partai atau perilaku partai. Pada umumnya sentimen anti partai muncul sebagai proses sosialisasi primer jangka panjang, dan atau respon warga negara terhadap ketidakpuasan penampilan partai politik dalam pemerintahan, pengelolaan organisasi partai, dan partai di akar rumput. ${ }^{10}$

Untuk mengantisipasi terus merosotnya persepsi negatif dan ketertarikan masyarakat untuk bergabung menjadi anggota parpol ini telah diantisipasi oleh pemebntuk UU dengan memberikan kesempatan kepada semua parpol untuk membentuk Organisasi Sayap Parpol (OSP). Kebijakan ini dimulai sejak disahkannya Undang-Undang Nomor 2 Tahun 2008 tentang Partai Politik. Pasal 12 huruf j UU Partai Politik (Parpol) menyatakan, "Partai Politik berhak membentuk dan memiliki organisasi sayap Partai Politik”. Menurut Penjelasan Pasal 12 huruf j UU No. 2 Tahun 2008, yang dimaksud dengan Organisasi Sayap Partai Politik adalah organisasi yang dibentuk oleh dan/atau menyatakan diri sebagai sayap Partai Politik sesuai dengan AD dan ART masing-masing Partai Politik.

Saat ini, hampir semua partai politik di Indonesia telah memiliki sayap parpol. Pada umumnya, pembentukan OSP terdiri dari segmen kelompok masyarakat perempuan, pemuda-mahasiswa, dan ulama. Mengapa tiga segmen masyarakat itu yang kebanyakan menjadi fokus dalam pembentukan OSP? M. Djadijono memberikan penjelasan sebagai berikut:

Dimasukkannya segmen perempuan sebagai komponen OSP antara lain karena jumlah mereka sangat banyak. sementara dimasukkannya kalangan pemuda dan mahasiswa sebagai salah satu segmen OSP selain karena jumlah mereka cukup besar, juga karena generasi muda dan mahasiswa dipandang sebagai "energi baru" dalam ikut serta menggerakkan dan melaksanakan fungsi-fungsi Parpol. Sebab mereka umumnya memiliki stamina yang lebih kuat dan beban tanggungan keluarga yang lebih ringan dibandingkan dengan generasi yang lebih tua. Dengan demikian pemuda dan mahasiswa menempati posisi yang cukup strategis pula bagi Parpol. Sedangkan

8 Sandro Gatra, Survei: Kedekatan dengan Parpol Rendah, Politik Uang Tinggi, https://nasional.kompas.com/read/2013/12/12/1709332/Survei.Kedekatan.dengan.Parpol.Rendah.Politik.Uan g. Tinggi, diakses tanggal 14 April 2019

${ }^{9}$ Firman Noor, Kegagalan Partai Politik Menarik Simpati Rakyat: Urgensi Sebuah Paradigma Baru Partai Politik, Jurnal Penelitian Politik, Vol. 4, No. 1, 2007, hlm. 50.

${ }^{10}$ Menurut Torcal, dkk. terdapat dua bentuk sentimen anti partai: Pertama, anti-partaisme reaktif yaitu sebuah sikap kritis dari warga negara dalam merespon ketidakpuasan mereka terhadap kinerja elit dan institusi partai penilaian negatif ini adalah produk dari adanya kontras antara inkonsistensi antara janji, label ideologi, dan retorika politisi, di satu sisi, dan persepsi warganegara tentang kinerja aktual dari demokrasi dan elit politik pada sisi yang lain. Kedua, anti-partaisme kultural yaitu ekspresi ketidak senangan terhadap eksistensi partai politik dalam sebuah negara. Berbeda dengan anti partaisme reaktif, yang masih mentoleransi kehadiran partai politik tetapi warganegara kecewa dengan kinerja partai, pada anti partaisme kultural warganegara tidak menyukai hadirnya partai politik itu sendiri. Sigit Pamungkas, Partai Politik: Teori Dan Praktik di Indonesia, edisi revisi, Institute for Democracy and Welfarism, Yogyakarta, 2012, hlm. 225-226 
dimasukkarmya ulama sebagai salah satu segmen OSP karena mereka memiliki posisi yang cukup strategis. Para ulama pada umummya memiliki pengikut tradisional, dan biasanya, pengikut tradisional ini mengikuti saja apa yang dianjurkan oleh ulamanya. Dengan demikian para ulama diharapkan dapat menjadi penarik umatnya untuk mendukung Parpol pemilik OSP yang bersangkutan. ${ }^{11}$

Tujuan dibentuknya OSP adalah sebagai pelaksana kebijakan Partai dan umtuk memenuhi kebutuhan strategis dalam rangka memperkuat basis dukungan Partai, serta untuk memperkuat fungsi dan peran Partai di masyarakat. Hal itu dapat disimak antara lain pada Anggaran Dasar Partai Golkar dan Partai Demokrasi Pembaruan. Tujuan yang ingin dicapai oleh Partai-partai lain-pun tampaknya tidak jauh berbeda dengan Partai Golkar dan PDP. ${ }^{12}$ Tulisan ini akan mencoba untuk membahas dan menganalisa faktor-faktor yang menjadi penyebab menurunnya keanggotaan dan kepercayaan masyarakat terhadap parpol dan bagaimana peran organisasi sayap parpol dalam mendongkrak keanggotaan parpol.

\section{B. Perspektif Perbandingan}

Penurunan keanggotaan dan kepercayaan masyarakat terhadap partai politik ternyata bukan hanya fenomena yang terjadi di Indonesia tetapi telah menjadi tren yang mengglobal. Menurut Pippa Norris, di banyak negara demokrasi yang sudah mapan, ada bukti bahwa keanggotaan partai telah terkikis, hubungan antara pemilih dan partai lemah, dan ada indikator bahwa partai politik semakin tidak dipercaya oleh publik. ${ }^{13}$ Tren ini umum terjadi di semua negara demokrasi utama, terutama terjadi pada kelompok usia muda. ${ }^{14}$ Di beberapa negara, penurunan jumlah anggota parpol setara dengan 5 persen pemilih, dan dalam kasuskasus ekstrem, penurunannya melebihi 10 persen. Singkatnya, penelitian yang tersedia saat ini menyimpulkan terjadinya penurunan yang besar dan konsisten anggota-anggota partai di seluruh Eropa. ${ }^{15}$ Penelitian dari Ingrid van Biezen dan Thomas Poguntke menunjukkan bahwa keanggotaan partai di Eropa telah menurun sejak tahun 1960, ketika hampir 15 persen pemilih di negara demokrasi Eropa berafiliasi dengan partai politik. Pada tahun 1980, bagian itu menyusut menjadi 10 persen, dan kemudian menjadi lima persen pada tahun 2008 . Beberapa penurunan terbesar sejak 1980 adalah di Austria dan Negara-negara Nordik di Finlandia, Norwegia, dan Swedia, di mana keanggotaan partai menurun antara 5 dan 11 poin persentase. ${ }^{16}$ Sementara itu, Susan Scarrow menemukan bahwa bagian pemilih Australia yang berasal dari partai-partai politik menurun lebih dari setengah antara tahun 1970-an dan 1990-an - dari hampir empat persen menjadi 1,5 persen - dan di Selandia Baru turun hampir 22 persentase dari tahun 1950 ke tahun $1990 .{ }^{17}$

${ }^{11}$ M. Djadijono, Formulasi Hubungan Parpol dengan Organisasi Sayap Partai, Analisis CSIS Vol. XXXVII, No. 2 Tahun 2008, hlm. 210-211

${ }^{12}$ Ibid, hlm. 209

${ }^{13}$ Pippa Norris, Building Political Parties: Reforming Legal Regulations and Internal Rules, Report Commissioned by International IDEA, 2004, hlm. 15

${ }^{14}$ Marc Hooghe \& Anna Kern, Party Membership and Closeness and the Development of Trust in Political Institutions, An Analysis of the European Social Survey, 2002-2010, Party Politics November 27, 2013, hlm. 5

${ }^{15}$ Sara Persson, The Effects of Party Membership Decline: A Cross-Sectional Examination of the Implications of Membership Decline on Political Trust in Europe, Bachelor Thesis in Political Science, Spring 2016, hlm. 7

${ }^{16}$ Ingrid van Biezen and Thomas Poguntke, "The Decline of Membership-based Politics", Party Politics, volume 20, issue 2, 2014, hlm. 206-208

17 Patrick Liddiard, Are Political Parties in Trouble?, terdapat dalam https://www.wilsoncenter.org/publication/are-political-parties-trouble\#_edn8, diakses tanggal 14 April 2019 
Hal yang sama juga terjadi di Inggris. Menurut Andrew Defty, telah terjadi penurunan jangka panjang dalam keanggotaan partai-partai politik arus utama di Inggris. Pada pertengahan 1950-an keanggotaan Partai Konservatif berjumlah sekitar 3 juta sementara Partai Buruh memiliki sekitar 1 juta anggota. Pada saat pemilihan umum 2015, Partai Konservatif memiliki keanggotaan sekitar 150.000 sementara keanggotaan Partai Buruh berjumlah sekitar 270.000. Beberapa tahun terakhir telah terlihat peningkatan keanggotaan dari beberapa partai kecil, terutama UKIP, SNP dan Partai Hijau, tetapi ini belum mengkompensasi penurunan keseluruhan keanggotaan partai di Inggris. Hanya sekitar 1\% dari populasi Inggris sekarang menjadi anggota partai politik. Meskipun keanggotaan partai telah menurun di seluruh Eropa Barat, tetapi saat ini Inggris memiliki tingkat keanggotaan partai terendah di Eropa. ${ }^{18}$

Untuk memperkuat data tentang penurunan keanggotaan parpol di berbeagai negara utamanya di negara-negara Eropa. Berikut disajikan data dari Alexander C. Tan tentang bukti penurunan anggota parpol seperti terlihat dalam tabel berikut: ${ }^{19}$

Tabel 3: Jumlah Anggota Partai Politik di Enam Negara Eropa

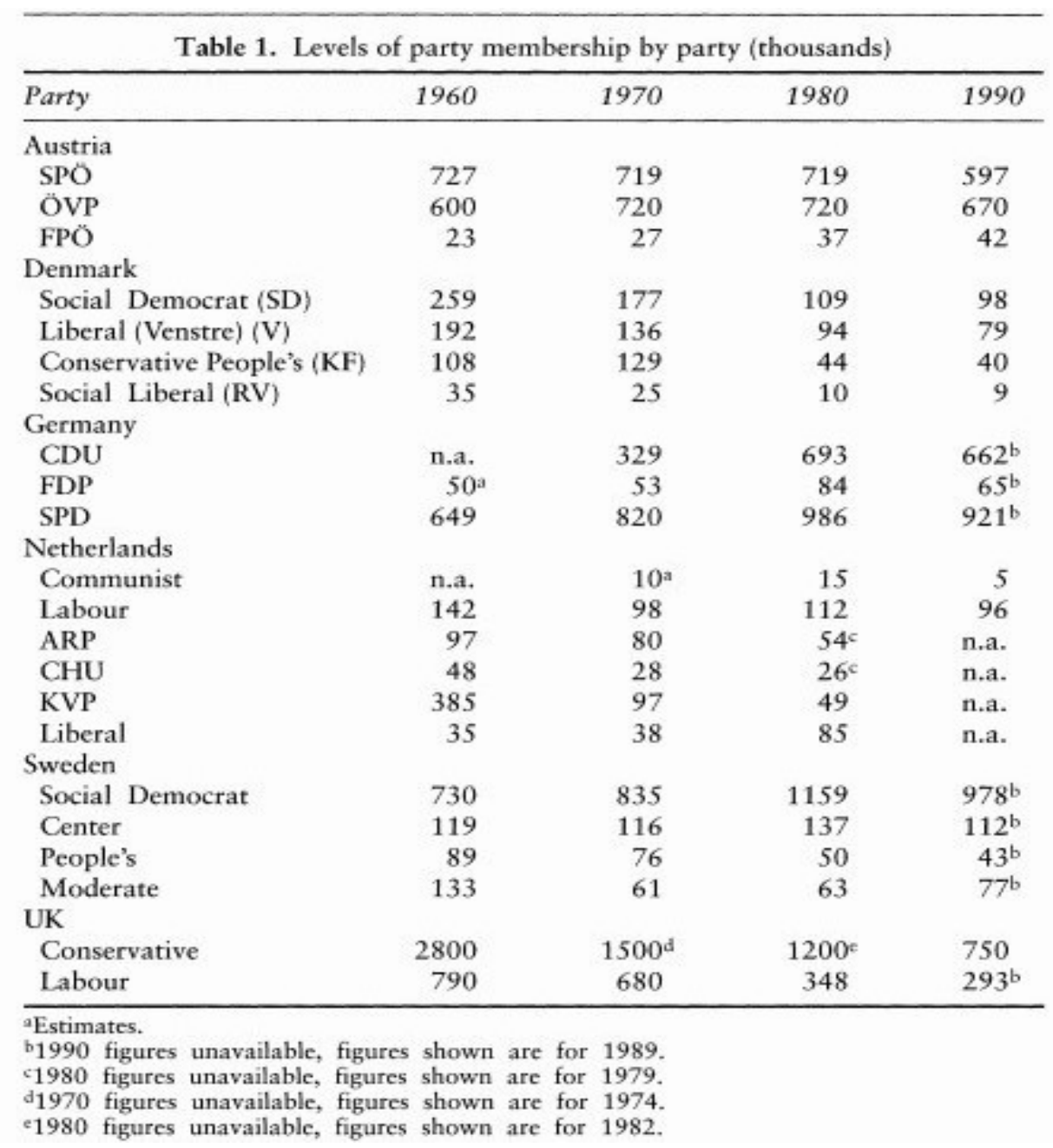

18 Andrew Defty, Fewer and older: Consequences of the decline in party membership in the UK, terdapat dalam http://www.democraticaudit.com/2015/11/13/fewer-and-older-consequences-of-the-declinein-party-membership-in-the-uk/, diakses tanggal 14 April 2019

${ }^{19}$ Richard S Katz and Peter Mair, eds, Party Organization: A Data Handbook, Sage, London, 1992 , sebagaimana dikutip oleh Alexander C. Tan, Party Change and Party Membership Decline: An Exploratory Analysis, Party Politics, Vol 3, Issue 3, 1997, hlm. 366 
Selain minimnya angka ketertarikan masyarakat di negara-negara demokrasi yang sudah mapan untuk bergabung menjadi anggota parpol, kepercayaan merekapun terhadap parpol juga rendah. Hal ini dapat dilihat dari hasil Survei Eurobarometer yang membandingkan citra partai di seluruh negara anggota Uni Eropa. Menggunakan data tahun 2004 sebagai contoh, memang ada beberapa variasi tingkat kepercayaan pada partai di seluruh negara Uni Eropa, tetapi tidak banyak. Proporsi parpol yang dipercaya berkisar dari yang tertinggi 32 persen di Denmark hingga 10 persen di Inggris. Tidak ada parpol yang mendapatkan kepercayaan yang signifikan. Walaupun ada beberapa variasi selama tujuh tahun terakhir, pola keseluruhannya adalah salah satu konsistensi umum. Dilihat dari segi lintas negara, pandangan negatif terhadap partai politik adalah fitur (gejala) umum dari opini publik kontemporer. Para pemilih tidak memiliki kepercayaan pada partai-partai baik di negara-negara besar atau kecil, di negara dengan ekonomi kuat atau lemah, di negara dengan sistem pemilihan umum mayoritas (distrik) atau proporsional, dan karakteristik sistemik lainnya. ${ }^{20}$ Adapun informasi lebih rinci tersaji dalam tabel berikut ini.

Tabel 4: Hasil Survei Eurobarometer tentang Kepercayaan Masyarakat Terhadap Parpol TRUST IN POLITICAL PARTIES BY NATION (1997-2004)

\begin{tabular}{lccccccccr}
\hline & $\mathbf{1 9 9 7}$ & $\mathbf{1 9 9 9}$ & $\mathbf{2 0 0 0}$ & $\mathbf{2 0 0 1}$ & $\mathbf{2 0 0 2}$ & $\mathbf{2 0 0 3}$ & $\mathbf{2 0 0 4}$ & Average & Net Change \\
\hline Austria & 24 & 22 & 21 & 25 & 25 & 20 & 19 & 22 & -5 \\
Belgium & 10 & 17 & 21 & 19 & 22 & 22 & 20 & 18 & 10 \\
Denmark & 31 & 27 & 32 & 36 & 35 & 37 & 32 & 33 & 1 \\
Finland & 14 & 20 & 20 & 22 & 21 & 24 & 21 & 20 & 7 \\
France & 12 & 11 & 15 & 15 & 13 & 15 & 13 & 13 & 1 \\
Germany & 13 & 18 & 17 & 17 & 17 & 11 & 11 & 15 & -2 \\
Greece & 20 & 20 & 19 & 25 & 16 & 17 & 28 & 21 & 8 \\
Ireland & 20 & 21 & 22 & 28 & 24 & 20 & 23 & 23 & 3 \\
Italy & 13 & 16 & 13 & 13 & 15 & 15 & 13 & 14 & 0 \\
Luxembourg & 31 & 27 & 41 & 32 & 32 & 31 & 31 & 32 & 0 \\
Netherlands & 40 & 40 & 39 & 34 & 35 & 33 & 27 & 35 & -13 \\
Portugal & 14 & 19 & 18 & 22 & 21 & 21 & 16 & 19 & 2 \\
Spain & 20 & 19 & 28 & 23 & 24 & 23 & 27 & 23 & 7 \\
Sweden & 16 & 17 & 16 & 22 & 23 & 20 & 21 & 19 & 5 \\
UK & 18 & 16 & 14 & 16 & 15 & 13 & 10 & 15 & -7 \\
EU 15 & $\mathbf{1 6}$ & $\mathbf{1 8}$ & $\mathbf{1 8}$ & $\mathbf{1 8}$ & $\mathbf{1 8}$ & $\mathbf{1 6}$ & $\mathbf{1 6}$ & $\mathbf{1 7}$ & $\mathbf{0}$ \\
\hline
\end{tabular}

Note: Table entries are the percentage 'tending to trust' political parties.

Berdasarkan data di atas, Russell J. Dalton dan Steven A. Weldon menyimpulkan bahwa:

In summary, contemporary publics appear to view political parties as democracy's necessary evil - needed for running elections and organising government, but with doubts about how political parties represent their interests within this process. Moreover, the negative sentiments toward political parties have spread over the past generation. Whereas academics and citizens alike once saw political parties as the pillars of democracy, contemporary publics now see them as unresponsive, untrustworthy, and unrepresentative. If democracy without parties is unthinkable, many citizens today are sceptical about how well parties perform this democratic role. $^{21}$

Singkatnya, publik kontemporer tampaknya memandang partai-partai politik sebagai kejahatan demokrasi yang diperlukan - diperlukan untuk mengikuti pemilihan umum

\footnotetext{
${ }^{20}$ Russell J. Dalton dan Steven A. Weldon, Op, Cit., hlm. 936

${ }^{21}$ Ibid, hlm. 937
} 
dan mengorganisir pemerintah, tetapi dengan keraguan tentang bagaimana partaipartai politik mewakili kepentingan mereka dalam proses ini. Selain itu, sentimen negatif terhadap partai politik telah menyebar ke generasi sebelumnya. Sementara akademisi dan warga negara pernah melihat partai politik sebagai pilar demokrasi, publik kontemporer sekarang melihat partai sebagai tidak responsif, tidak dapat dipercaya, dan tidak representatif. Jika demokrasi tanpa partai adalah mustahil, banyak warga negara saat ini skeptis tentang seberapa baik partai melakukan peran demokratis ini.

\section{Faktor-Faktor yang Mempengaruhi Kemerosotan Keanggotaan Partai Politik}

Menurut hipotesis Marc Hooghe \& Anna Kern, keanggotaan partai dan perasaan dekat dengan partai politik berkontribusi pada pengembangan kepercayaan politik, karena hal ini memberikan warga negara kesempatan untuk mengekspresikan pendapatnya dengan cara yang lebih efektif dan memungkinkan mereka untuk berhubungan dengan prosedur demokratis secara umum. Oleh karena itu, fenomena menurunnya jumlah anggota partai politik dan tingkat kedekatan yang rendah dengan partai politik, merupakan tanda rendahnya tingkat kepercayaan politik secara umum. Padahal, kepercayaan politik penting, karena berkaitan dengan kemauan masyarakat dalam memberikan wewenang kepada negara untuk mengatur bagian yang lebih besar dari pengaturan masyarakat. Kepercayaan politik juga dapat dilihat sebagai sumber penting dukungan yang luas untuk sistem politik, dan kecenderungan yang menurun dalam kepercayaan politik akan membuat lembaga pemerintah lebih sulit untuk memerintah secara efektif. ${ }^{22}$

Lebih jauh lagi, keanggotaan partai dan identifikasi partai yang telah terkikis secara dratis menyiratkan bahwa bagi sebagian besar (mayoritas) warga negara, parpol tidak bisa lagi menjadi alat untuk memungkinkan masyarakat berhubungan secara efektif dengan sistem politik. Padahal salah satu fungsi penting parpol adalah menjadi jembatan penghubung (link) antara rakyat dan pemerintah. ${ }^{23}$

Menurut analisis para ahli seperti Peter Mair misalnya, mensinyalir tiga faktor penyebab penurunan keanggotaan partai politik, yaitu: ${ }^{24}$ Pertama, partai-partai politik saat ini posisinya sudah lebih "kuat", karena mereka memiliki lebih banyak akses ke kekuasaan atau pemerintahan. Struktur partai politik telah berubah dengan cepat. Sebagaimana disampaikan oleh Katz dan Mair (1995), bahwa partai-partai politik dengan cepat mengadopsi model kartel di mana tujuan utama partai adalah untuk memenangkan pemilihan sehingga memungkinkan parpol untuk mendapatkan akses ke kekuasaan dan sumber daya pemerintah. Pada saat yang bersamaan parpol mengabaikan peran ideologis mereka atau hubungannya dengan basis keanggotaan mereka. Dalam partai politik profesional, elite-elite partai yang jumlahnya sangat kecil menjadi penentu dalam merumuskan taktik dan strategi kampanye. Proses profesionalisasi ini memiliki konsekuensi penting bagi fungsi tradisional partai politik dalam sistem politik. Anggota partai semakin dianggap sebagai fitur usang, karena partai tidak lagi tergantung secara finansial pada kontribusi anggota. Mempertimbangkan fakta bahwa anggota partai akan termotivasi secara ideologis, dianggap akan menghalangi preferensi elite partai untuk memaksimalkan suara dan kekuasaan. Oleh karena itu, peran anggota tidak lagi banyak diharapkan untuk berpartisipasi secara aktif dalam semua jenis kegiatan partai, atau untuk berkontribusi pada kampanye pemilu yang

\footnotetext{
${ }^{22}$ Marc Hooghe \& Anna Kern, Op, Cit., hlm.2-7

${ }^{23}$ Samuel J. Eldersveld and Hanes Walton, Jr., Political Parties in American Society, Second Edition, Boston, New York, hlm. 2

24 Peter Mair, Political Parties, Popular Legitimacy and Public Privilege, West European Politics, volume 18, issue 3 (1995).
} 
telah menjadi sangat profesional yang saat ini berfokus hampir secara eksklusif pada media massa dan teknologi informasi baru. ${ }^{25}$

Berbagai literatur menyatakan bahwa partai-partai politik modern memiliki sedikit kebutuhan untuk keanggotaan massal, yang telah menurun tajam di Eropa Barat dalam 4050 tahun terakhir. Kampanye profesional yang dibayar oleh subsidi publik diduga mengurangi nilai pemilihan tingkat dan jumlah anggota. Karenanya, sebagian besar partai tampaknya relatif tidak peduli tentang keanggotaan mereka dan malah lebih fokus untuk menjangkau masyarakat luas melalui teknik kampanye dan pemasaran profesional. Para ahli telah lama mengidentifikasi proses sosial dan teknologi yang diduga membuat partai-partai kurang tertarik untuk mendaftarkan anggota. Inti dari argumen ini adalah substitusi dari anggota dalam kampanye modern. Menurut Kirchheimer, para pemimpin partai dalam upaya politik pasca-kelas untuk 'menjaring semua' pemilih. Televisi menjadi arena dominan kompetisi pemilihan, dalam apa yang dicirikan oleh Wiesendahl sebagai 'Copernican turn' dalam kampanye. Sejak tahun 1950-an, yang umumnya dianggap sebagai 'masa keemasan' keanggotaan massa, McKenzie melihat banyak bukti di Inggris tentang media baru yang menjadikan fungsi pemilihan anggota tradisional jauh lebih tidak penting. Jadi, menurut Epstein perkembangan yang dipimpin AS, 10 medialisasi dan profesionalisasi politik Eropa Barat pada periode pasca-perang dikatakan telah menyebabkan penurunan peringkat umum dari organisasi keanggotaan konvensional, sehingga memunculkan partai yang padat modal untuk menjaring semua pihak (mendapatkan suara sebanyak-banyaknya). ${ }^{26}$

Kedua, salah satu fungsi penting keberadaan anggota parpol adalah untuk menjadi sumber pendapatan bagi parpol melalui iuran anggota. Oleh karena itu, menurut Andrew Defty, The most obvious consequence of declining membership is that parties have faced a decline in revenue from membership fees (Konsekuensi paling jelas dari menurunnya keanggotaan adalah bahwa partai politik telah menghadapi penurunan pendapatan dari biaya keanggotaan). ${ }^{27}$ Saat ini, sebagian besar parpol di Eropa telah memiliki lebih banyak uang daripada sebelumnya. Partai-partai di semua negara Eropa telah melaporkan pertumbuhan substansial dalam pendapatan partai dalam bentuk riil selama dua dekade terakhir. Jadi, partai-partai di Denmark, misalnya, meskipun telah kehilangan sebagian besar keanggotaan mereka, sekarang menghasilkan 50 persen lebih banyak pendapatan daripada 20 tahun yang lalu; di Irlandia, pendapatan partai meningkat lebih dari dua kali lipat pada periode yang sama; di Austria, jumlahnya meningkat hampir empat kali lipat. Bahkan di Belanda, di mana keuangan partai selalu luar biasa 'sederhana', partai-partai sekarang 40 persen lebih kaya secara riil daripada 20 tahun yang lalu.

Ketiga, bukti meningkatnya sumber daya partai juga dapat dilihat dalam hal meningkatnya jumlah staf dan personil partai. Dengan demikian, hampir tanpa pengecualian, partai sekarang memiliki staf yang jauh lebih baik daripada 20 tahun yang lalu, dengan jumlah birokrat partai profesional meningkat lebih dari dua kali lipat di Denmark, misalnya, lebih dari tiga kali lipat di Jerman, dan lebih dari empat kali lipat, di Irlandia. Akhirnya, partai-partai telah mendapatkan akses yang meningkat ke sumber daya perlindungan, yang menawarkan sumber kekuatan lain.

Di luar ketiga faktor di atas, fenomena penyalahgunaan kekuasaan (abuse of power) dan perilaku koruptif parpol juga telah mempengaruhi minat seseorang untuk bergabung dengan parpol. Hasil survey Global Corruption Barometer 2004 yang menanyakan kepada publik di 62 negara tentang seberapa besar korupsi mempengaruhi berbagai institusi politik

\footnotetext{
${ }^{25}$ Marc Hooghe \& Anna Kern, Op, Cit., hlm. 3-4

${ }^{26}$ Hilmar Langhelle Mjelde, How and Why Parties Respond to Membership Decline: The Case of the SPD and the CDU, German Politics, Volume 22, Issue 3 (2013), hlm. 253-254

${ }^{27}$ Andrew Defty, Op, Cit.
} 
dan sosial, partai-partai politik adalah lembaga yang paling sering dikutip untuk masalah korupsi mereka. Dari 17 dari 20 demokrasi Barat yang termasuk dalam proyek ini, partaipartai politik dinilai sebagai institusi yang paling terpengaruh oleh korupsi. ${ }^{28}$

Selain itu, terjadinya pergeseran atau perubahan fungsi parpol. Secara tradisional, partai politik berfungsi sebagai salah satu jembatan utama yang menghubungkan antara warga negara dan negara. Partai politik mensosialisasikan warga negara ke dalam politik, mereka menggabungkan preferensi dan menyediakan mekanisme untuk identifikasi dengan sistem politik dan peran yang dapat dimainkan warga dalam sistem itu. Partai-partai politik juga berfungsi sebagai mekanisme hubungan ideologis, yang memungkinkan warga negara untuk mengidentifikasi isu-isu kebijakan yang relevan dan posisi mereka dalam isu-isu tersebut. Dengan menawarkan serangkaian solusi kebijakan yang diilhami secara ideologis dan pokok-pokok agenda politik, partai membangun debat politik, menjadikannya lebih mudah bagi setiap warga negara untuk memahami politik. Oleh karena itu, secara tegas dinyatakan bahwa partai-partai politik secara efektif "mengatur demokrasi". Namun, saat ini semakin banyak fungsi partai politik telah berubah karena penekanan telah bergeser dari partai sebagai gerakan politik yang diilhami secara ideologis dan organisasi anggota, menuju 'partai untuk pemerintahan' ('the party in office'). Profesionalisasi politik partai ini menyiratkan bahwa mekanisme keterkaitan penting yang tersedia bagi warga negara telah melemah. ${ }^{29}$

Sebab lainnya, memudarnya identifikasi warga dengan parpol tertentu juga dipengaruhi oleh sistem kepartaian. Identifikasi warga dengan parpol tertentu menjadi lebih sulit dalam sistem multipartai (karena banyaknya pilihan parpol) dibandingkan dengan dwi partai. Hal ini disampaikan oleh Rosema, bahwa: ${ }^{30}$

In two-party systems, like the United States, the concept of party identity is routinely used, as it is assumed that citizens have a stable preference for one of the two main political parties. In multiparty systems, on the other hand, this kind of preference is less clearly defined and citizens can even hold different preferences simultaneously.

Dalam sistem dua partai, seperti Amerika Serikat, konsep identitas partai secara rutin digunakan, karena diasumsikan bahwa warga negara memiliki preferensi yang stabil untuk salah satu dari dua partai politik utama. Di sistem multipartai, di sisi lain, jenis preferensi ini kurang jelas dan warga negara bahkan dapat memiliki preferensi yang berbeda secara bersamaan.

Pendapat lainnya menyatakan bahwa keberpihakan seseorang terhadap parpol menurun karena warga memperoleh lebih banyak keterampilan politik sementara pada saat yang sama, media massa telah banyak tersedia sehingga menurunkan biaya informasi. Sebagai akibatnya warga negara menjadi semakin lebih mampu mengarahkan diri mereka sendiri dalam lanskap politik yang kompleks tanpa bergantung pada ikatan partisan. Menurut teori mobilisasi kognitif ini, kenaikan tingkat pendidikan dan penyebaran media massa membuat keterikatan partai semakin usang. Mengikuti teori ini, terdapat hubungan langsung antara kenaikan tingkat pendidikan dan penyebaran media massa di satu sisi, dan identifikasi partai di sisi lain. ${ }^{31}$

${ }^{28}$ Russell J. Dalton dan Steven A. Weldon, Op, Cit., hlm. 936

${ }^{29}$ Marc Hooghe \& Anna Kern, Op, Cit., hlm. 2

${ }^{30}$ Ibid, hlm. 4-5

${ }^{31}$ Anna Kern, Partisanship and Satisfaction with Democracy: A Longitudinal Analysis of the Linkage between Citizens and the State, Paper, prepared for the ECPR General Conference - University of Glasgow 3-6 September 2014, hlm. 5 
Namun demikian, tidak semua pakar setuju dengan klaim bahwa proses mobilisasi kognitif secara langsung memengaruhi keterikatan partisan. Para ahli seperti Bardi, Bartolini, Trechsel, van Biezen dan Poguntke mengklaim bahwa keberpihakan telah terkikis karena, meningkatnya tingkat pendidikan menyebabkan perubahan stratifikasi sosial masyarakat yang pada gilirannya melemahkan ikatan partisan. Argumennya adalah bahwa dengan meningkatnya tingkat pendidikan, hubungan istimewa antara kelompok-kelompok tradisional warga negara (misalnya pekerja atau jemaah gereja) dan parpol terkait melemah. Proses ini menyebabkan kaburnya perbedaan kelas dan munculnya perpecahan postmaterialis. Ketika warga kurang mengenal kelompok-kelompok tradisional ini dan ketika sistem nilai baru muncul, keberpihakan semakin berkurang. Argumen ini dikonfirmasi oleh Arzheimer yang menunjukkan bahwa penurunan keberpihakan terhadap paprol di Jerman terutama disebabkan oleh melemahnya ikatan sosial tradisional. Dalam dua dasawarsa pertama Republik Federal Jerman, para pemilihnya sebagian besar diidentifikasikan dengan dua partai besar: Para jemaah gereja sebagian besar diidentifikasi dengan Partai Kristen Demokrat (CDU / CSU), pekerja kerah biru (blue-collar workers) - merupakan tipe pekerja yang tidak mempunyai keterampilan khusus - mewakili pemilih umum untuk Partai Sosial Demokrat (SPD). Identifikasi partai dengan demikian berevolusi terutama di sepanjang kelas dan agama, dua perpecahan paling penting dalam masyarakat Jerman selama periode itu. ${ }^{32}$

Faktor kunci lain yang secara umum dianggap telah merusak kebutuhan akan banyaknya keanggotaan parpol adalah pengenalan subsidi publik. Dengan perbedaan yang semakin besar antara dana sumbangan anggota parpol dengan pengeluaran partai, subsidi negara diperkenalkan pada 1950-an untuk mempertahankan kegiatan partai-partai di luar parlemen. Negara-negara Amerika Latin (Kosta Rika 1954, Argentina 1955) memelopori praktik ini, sementara Jerman Barat, pada tahun 1959, adalah yang pertama di Eropa Barat. ${ }^{33}$ Sejak saat itu, berbagai subsidi publik telah dilembagakan di seluruh dunia. Selanjutnya, Ponce dan Scarrow mencatat bahwa sumbangan individu membentuk sumber dana yang kurang dimanfaatkan untuk partai. ${ }^{34}$ Karena perubahan-perubahan ini, biaya keanggotaan massal sekarang dikatakan lebih besar daripada manfaatnya. Anggota direkrut melalui insentif non-material dan material, misalnya kesempatan untuk mempengaruhi kebijakan partai. ${ }^{35}$ Singkatnya, partai-partai telah kehilangan minat dalam keanggotaan massal, karena sumber daya pemilu yang baru secara bertahap telah menggantikannya.

\section{Peran Organisasi Sayap Partai Politik (OSP) dalam Meningkatkan Keanggotaan Parpol di Indonesia}

Salah satu peran penting Partai adalah mempertahankan sistem politik yang sah dan demokratis. Lebih jauh, fungsi utama partai adalah untuk membangun dan menegakkan hubungan yang representatif antara negara dan masyarakat. Dalam konteks ini, anggota partai politik telah bertindak sebagai sumber informasi penting mengenai kebutuhan masyarakat sehingga menambahkan input dalam proses kebijakan, membantu dalam pembentukan program partai. Selain itu, anggota partai juga berfungsi sebagai perekat masyarakat di akar rumput ke elit partai. Selain itu, basis keanggotaan telah menjadi sumber rekrutmen untuk perwakilan partai. ${ }^{36}$

\footnotetext{
${ }^{32}$ Ibid, hlm. 5-6

${ }^{33}$ Karl-Heinz Nassmacher, 'Structure and Impact of Public Subsidies to Political Parties in Europe: The Examples of Austria, Italy, Sweden and West Germany', dalam H.E. Alexander (ed.), Comparative Political Finance in the 1980s, Cambridge University Press, Cambridge, 1989, hlm. 238.

34 A.F. Ponce and S.E. Scarrow, Who Gives? Partisan Donations in Europe, West European Politics, volume 34, issue 5, 2011, hlm.997-1020.

${ }^{35}$ Klaus von Beyme, Political Parties in Western Democracies, Gower, Aldershot, 1985, hlm.171

${ }^{36}$ Sara Persson, Op, Cit., hlm. 4
} 
Oleh sebab itu, mayoritas masyarakat setuju dan mengakui akan peran dan fungsi penting anggota partai. Kenyataannya, yang terjadi justru adalah penurunan jumlah anggota parpol secara terus-menerus dan ekstensif dalam beberapa dekade terakhir. Tren penurunan ditemukan di hampir semua negara demokrasi mapan maupun baru. Secara bersamaan, identifikasi partai serta tingkat kepercayaan terhadap partai juga melemah. Selain itu, jumlah pemilih dalam pemilu telah menurun di banyak negara Eropa yang menunjukkan sinyal volatilitas (pemilih yang tidak loyal). Hal ini mengindikasikan adanya peningkatan gap (keterasingan) antara warga negara dan ranah politik. Tren penurunan ini pasti memiliki implikasi bagi partai-partai, serta hubungan antara negara dan masyarakat karena partai politik berfungsi menyediakan mekanisme keterkaitan struktural antara warga negara dan sistem politik. Karena itu, Whiteley secara tegas menyatakan bahwa, penurunan keanggotaan parpol dapat mengarah pada hasil negatif bagi stabilitas rezim demokratis. ${ }^{37}$

Salah satu fungsi yang sering ditekankan untuk anggota partai adalah bahwa keberpihakan politik memungkinkan warga untuk memahami kompleksitas politik. Lebih jauh, seberapa banyak catatan tentang jumlah partisan dan anggota politik dapat digunakan sebagai tanda untuk mengungkapkan tingkat kepercayaan yang lebih tinggi terhadap partai dan sistem politik. Sederhananya, partai politik mengintegrasikan anggota ke dalam sistem, yang dimanifestasikan melalui tingkat dukungan yang lebih tinggi. Sementara partai berfungsi sebagai penghubung antara masyarakat dan negara, anggota bekerja sebagai mekanisme untuk fungsi-fungsi ini karena mereka berkontribusi pada legitimasi partai dan sistem. Namun, ketika anggota partai dan pengidentifikasian masyarakat terhadap parpol telah menurun, itu maknanya kekecewaan warga terhadap politik telah tumbuh. ${ }^{38}$

Keberpihakan (sikap partisan seseorang terhadap parpol) dibentuk untuk memungkinkan warga memperbaiki dan mengembangkan pandangan politik sebagai modal penting dalam rangka menghasilkan kesadaran politik yang diperlukan untuk mengatasi dan merespons sistem politik. Kesadaran politik yang tinggi dari warga negara adalah bagian penting dari demokrasi perwakilan, karena akan memperkuat kapasitas bagi warga negara dalam merespon dinamika politik dan mengartikulasikan kebutuhan masyarakat, yang pada akhirnya akan menciptakan sistem politik yang responsif. Harus disadari bahwa, sistem politik yang responsif adalah bagian penting dari proses demokrasi yang keberadaannya sangat bergantung pada kesadarn warga negara. Dengan demikian, keberadaan para aktor partisan menjadi penting dalam menegakkan cita-cita demokrasi.

Sejauh ini, para partisan dan anggota partai diperlukan untuk menghasilkan kepercayaan dan memungkinkan terciptanya legitimasi sistem. Fungsi anggota dan para partisan parpol sebagai "penghasil kepercayaan" akan membuat segala aktifitas politik akan lebih dapat diterima. Oleh karena itu, ketika tingkat keanggotaan turun, persepsi masyarakat tentang partai juga akan turun. Kepercayaan dapat dianggap sebagai bentuk persetujuan paling dasar yang melampaui evaluasi pemerintah yang berkuasa. Tentu saja, kepercayaan adalah ukuran persepsi sistem politik secara keseluruhan. Oleh karena itu, tingkat dukungan yang tinggi dapat dianggap sebagai indikasi keberhasilan negara dalam mengelola masyarakat. Oleh karena itu, jika anggota partai berfungsi sebagai "sumber kepercayaan", dan merupakan mekanisme bagi partai sebagai penghubung politik, basis keanggotaan yang besar mencerminkan kepercayaan sosial yang lebih tinggi terhadap partai, sistem kepartaian serta kapabilitas penyelenggara negara. Sebaliknya, basis keanggotaan yang menurun dan lemah adalah tercermin dari rendahnya tingkat kepercayaan dan dukungan bagi partai, sistem kepartaian dan terhadap kemampuan negara. ${ }^{39}$

\footnotetext{
${ }^{37}$ Marc Hooghe \& Anna Kern, Op, Cit., hlm. 18

${ }^{38}$ Sara Persson, $O p$, Cit., hlm. 7

${ }^{39}$ Ibid, hlm. 9
} 
Selain itu, keberadaan para partisan dan anggota partai juga akan memiliki efek simbolis bagi partai. Sebagaimana disampaikan oleh Scarrow \& Gezgor, bahwa: ${ }^{40}$

“...Party members often play a role in establishing the party 'brand'. One of the ways that parties may profit from their memberships results from the legitimacy members can provide: members have a symbolic role in the chain of representation. Party membership can boost a party's perceived authenticity by visibly symbolizing its support in the community- showing that it is not just an organization by and for elites." "... Anggota partai sering memainkan peran dalam membangun 'brand' partai. Salah satu cara parpol untuk dapat mengambil untung dari keanggotaan mereka adalah dari anggota yang sah yang dapat disediakan oleh anggota: anggota parpol memiliki peran simbolis dalam rantai perwakilan. Keanggotaan partai dapat meningkatkan persepsi keaslian sebuah partai dengan secara nyata melambangkan dukungannya di masyarakat - sehingga menunjukkan bahwa partai bukan hanya sebuah organisasi oleh dan untuk elit.

Hal senada juga disampaikan oleh Sara Persson bahwa keberadaan anggota parpol memiliki nilai promosi bagi parpol itu sendiri. Selain itu, mereka juga mengakumulasi ikatan masyarakat yang mempengaruhi persepsi warga secara umum. Dengan kata lain, semua anggota partai berfungsi sebagai komunikator umum untuk parpol. Karena itu, kehilangan anggota yang sangat besar, akan menyebabkan partai-partai kehilangan komunikator politik yang penting sehingga hubungan baik warga negara dengan partai-partai akan hilang atau setidaknya memudar. Dengan demikian, masyarakat akan kehilangan aktor yang berfungsi meningkatkan persepsi masyarakat tentang politik. Ketika partai-partai telah kehilangan promotor partai, semua partai akan kehilangan legitimasi politik, yang hal ini juga akan mempengaruhi pandangan masyarakat tentang sistem politik secara keseluruhan. ${ }^{41}$

Kesimpulannya, baik langsung maupun tidak langsung, fungsi anggota parpol sangat bernilai bagi partai serta sistem politik secara umum. Nilai langsungnya adalah, sebagai anggota menunjukkan tingkat kepercayaan yang lebih tinggi kepada parpol dan sistem daripada non-anggota. Nilai yang tidak langsung, keberadaan anggota parpol adalah penting untuk mekanisme partai sebagai penghubung antara negara dan masyarakat. Melalui hubungan yang kuat dengan masyarakat, politik menjadi saling mempertalikan, meningkatkan legitimasi bagi institusi negara. ${ }^{42}$ Selain itu, ketika partisan politik berkembang meningkatkan keterampilan politik warga negara, mereka menjadi sadar politik. Hal ini tentu akan mengarah pada kemampuan yang lebih tinggi untuk menyuarakan aspirasi masyarakat, membuat sistem politik lebih responsif. ${ }^{43}$

Melihat begitu penting peran dan fungsi keanggotaan partai, maka parpol harus selalu mengusahakan agar tidak terjadi penurunan keanggotaan yang bersifat masih dan dalam skala yang besar dari waktu ke waktu. Salah satu usaha yang dapat dilakukan untuk mencegah penurunan keanggotaan partai dan sekaligus untuk menaikkan ketertarikan warga negara ikut ikut bergabung menjadi anggota partai adalah dengan cara memaksimalkan peran dan fungsi organisasi sayap parpol. Hal ini sesuai dengan tujuan utama pembentukan

${ }^{40}$ Susan E. Scarrow and Burcu Gezgor, Declining Memberships, Changing Members? European Political Party Members in A New Era, Party Politics, volume 16, issue 6, 2010, hlm. 827.

${ }^{41}$ Sara Persson, Op, Cit., hlm. 8

${ }^{42}$ Christopher J. Anderson and Aida Just, Legitimacy From Above: The Partisan Foundations of Support for the Political System in Democracies, European Political Science Review, volume 5, issue 3, 2013, hlm. 357

${ }^{43}$ Jonathan White and Lea YPI, On Partisan Political Justification, American Political Science Review, volume 105 , issue 2, 2011, hlm. 387 
OSP itu sendiri yaitu antara lain dimaksudkan sebagai sumber kader dan pelaksana kebijakan Parpol serta penguat basis Parpol di tengah masyarakat yang saat ini cenderungg kehilangan kepercayaan terhadap Parpol.

Harapan bahwa dengan OSP, minat masyarakat untuk bergabung dengan parpol akan semakin tinggi karena OSP memiliki citra yang lebih baik di mata publik dibandingkan parpol induk organisasinya antara lain karena OSP belum tercemari oleh praktek-praktek politik kotor sebagaimana telah menimpa sementara kalangan elit Parpol di DPR seperti kasus suap, pelecehan seksual serta sering membolos pada rapat-rapat DPR. Hal ini berimplikasi pada rendahnya kepercayaan masyarakat kepada Parpol.

Sayangnya, kinerja organisasi sayap (underbow) partai politik sejauh ini relatif tumpul dan sekadar menjadi pajangan tanpa peta kerja yang jelas. Underbow partai hanya dijadikan alat untuk memberi wadah jabatan bagi segelintir elit partai sehingga kinerjanya hampir tidak ada yang menyentuh rakyat dan hanya menjalankan program-program pragmatis untuk mendapatkan jabatan dan kekayaan. ${ }^{44}$ Selain itu, menurut M. Djadijono posisi penting dan sentral OSP sebagai sarana untuk seluas-luasnya menarik minat orang menjadi simpatisan dan/atau anggota parpol masih mengalami banyak kendala, salah satunya adalah adanya ketidakjelasan pola dan tata hubungan antara OSP dengan partai politik induknya. Ketidakjelasan pola dan tata hubungan dimasksud meliputi: (1) Kedudukan dan fungsi OSP bagi Parpol pemiliknya; (2) Hak-hak dan kewajiban Parpol terhadap Pengurus, kader dan anggota OSP; (3) Kejelasan tentang hak-hak dan kewajiban OSP terhadap Parpol induknya; (4) Kejelasan tentang hak-hak OSP dalam proses pengambilan kebijakan dan keputusan dalam Parpol; dan (5) Kejelasan tentang hak-hak dan kewajiban Pengurus, kader dan anggota OSP dalam proses rekrutmen kepengurusan Parpol induknya maupun dalam proses rekrutmen jabatan-jabatan publik yang menjadi kewenangan Parpol induknya. ${ }^{45}$ Oleh sebab itu, beberapa ketidakjelasan relasi antara OSP dan Parpol induknya tersebut perlu diatur secara lebih jelas dalam masing-masing AD/ART Parpol, atau bahkan bila dirasa penting dan perlu, pengaturannya melalui UU Partai Politik.

\section{F. Penutup}

Partai politik adalah wadah bagi masyarakat dalam memperjuangkan kepentingan politiknya. Oleh karenanya, keanggotaan menjadi hal fundamental dalam parpol. Banyak studi telah menunjukkan arti penting anggota parpol, yaitu sebagai "penghasil kepercayaan" yang memungkinkan terciptanya legitimasi sistem politik, memberikan nilai promosi bagi parpol, mengembangkan pandangan politik warga masyarakat sebagai modal penting dalam rangka menghasilkan kesadaran politik, membangun tingkat kepercayaan masyarakat yang lebih tinggi terhadap partai dan sistem politik, dan lain sebagainya.

Ironinya, minat warga negara untuk menjadi partisan dan anggota parpol mengalami penurunan dari tahun ke tahun yang kondisinya sangat mengkawatirkan. Padahal, salah satu implikasi dari penurunan keanggotaan ini menjadi tanda bahwa ada kemerosotan kepecayaan pada parpol dan sistem politik secara umum. Oleh sebab itu, parpol perlu memikirkan startegi baru untuk menarik minat masyarakat agar kembali antusias berpartisipasi dalam kegiatan politik khususnya menjadi anggota parpol sehingga demokrasi akan berjalan dengan baik. Salah satu instrumen yang dapat digunakan oleh parpol untuk meningkatkan kembali ketertarikan masyarakat pada parpol adalah melalui wadah

44 Underbow partai masih tumpul, terdapat dalam https://nasional.sindonews.com/read/583640/12/underbow-partai-masih-tumpul-1330391180, diakses tanggal 14 April 2019

${ }^{45}$ M. Djadijono, Op, Cit., hlm. 220 
organisasi sayap parpol (OSP) yang keberadaannya secara hukum telah diakui dalam UU Partai Politik.

\section{Daftar Pustaka}

\section{Buku}

H.E. Alexander (ed.), 1989, Comparative Political Finance in the 1980s, Cambridge University Press, Cambridge.

Klaus von Beyme, 1985, Political Parties in Western Democracies, Gower, Aldershot.

Pippa Norris, Building Political Parties: Reforming Legal Regulations and Internal Rules, Report Commissioned by International IDEA, 2004.

Richard S. Katz, 1980, A Theory of Parties and Electoral System, The Johns Hopkins University Press, Baltimore.

Samuel J. Eldersveld and Hanes Walton, Jr., Political Parties in American Society, Second Edition, Boston, New York.

Sigit Pamungkas, 2012, Partai Politik: Teori Dan Praktik di Indonesia, edisi revisi, Institute for Democracy and Welfarism, Yogyakarta.

\section{Jurnal}

A.F. Ponce and S.E. Scarrow, 'Who Gives? Partisan Donations in Europe', West European Politics, volume 34, issue 5, 2011.

Alexander C. Tan, Party Change and Party Membership Decline: An Exploratory Analysis, Party Politics, Vol 3, Issue 3, 1997.

Christopher J. Anderson and Aida Just, "Legitimacy From Above: The Partisan Foundations of Support for the Political System in Democracies". European Political Science Review, volume 5, issue 3, 2013.

Firman Noor, Kegagalan Partai Politik Menarik Simpati Rakyat: Urgensi Sebuah Paradigma Baru Partai Politik, Jurnal Penelitian Politik, Vol 4, No 1, 2007.

Hilmar Langhelle Mjelde, How and Why Parties Respond to Membership Decline: The Case of the SPD and the CDU, German Politics, Volume 22, Issue 3, 2013.

Ingrid van Biezen and Thomas Poguntke, The Decline of Membership-based Politics, Party Politics, volume 20, issue 2, 2014.

Ingrid van Biezen, The Place of Parties in Contemporary Democracies, West European Politics, volume 26, issue 3, 2003.

Jonathan White and Lea YPI. "On Partisan Political Justification". American Political Science Review, volume 105, issue 2, 2011.

M. Djadijono, Formulasi Hubungan Parpol dengan Organisasi Sayap Partai, Analisis CSIS Vol. XXXVII, No. 2 Tahun 2008.

Marc Hooghe \& Anna Kern, Party Membership and Closeness and the Development of Trust in Political Institutions, An Analysis of the European Social Survey, 2002-2010, Party Politics November 27, 2013.

Peter Mair, Political Parties, Popular Legitimacy and Public Privilege, West European Politics, volume 18, issue 3, 1995.

Russell J. Dalton and Steven A. Weldon, Public Images of Political Parties: A Necessary Evil?, West European Politics, Vol. 28, No. 5, 931 - 951, November 2005.

Sara Persson, The Effects of Party Membership Decline: A cross-Sectional Examination of the Implications of Membership Decline on Political Trust in Europe, Bachelor Thesis in Political Science, Spring 2016. 
Susan E. Scarrow and Burcu Gezgor, Declining Memberships, Changing Members? European Political Party Members in A New Era. Party Politics, volume 16, issue 6, 2010.

\section{Makalah, Website dan Media Massa}

Anna Kern, Partisanship and Satisfaction with Democracy: A Longitudinal Analysis of the Linkage between Citizens and the State, Paper, prepared for the ECPR General Conference - University of Glasgow - 3-6 September 2014.

Djayadi Hanan, Parpol dan Persepsi Publik, Kompas, Sabtu, 11 April 2015.

Jumlah Pemilih Pemilu 2019 Bertambah Jadi 192.866.254", https://nasional.kompas.com/read/2019/04/08/21501411/jumlah-pemilih-pemilu2019-bertambah-jadi-192866254., diakses tanggal 14 April 2019

https://infopemilu.kpu.go.id/pileg2019/verpol/parpol, diakses tanggal 14 April 2019

Sandro Gatra, Survei: Kedekatan dengan Parpol Rendah, Politik Uang Tinggi, https://nasional.kompas.com/read/2013/12/12/1709332/Survei.Kedekatan.dengan.Par pol.Rendah.Politik.Uang. Tinggi, diakses tanggal 14 April 2019

Patrick Liddiard, Are Political Parties in Trouble?, terdapat dalam https://www.wilsoncenter.org/publication/are-political-parties-trouble\#_edn8, diakses tanggal 14 April 2019

Andrew Defty, Fewer and older: Consequences of the decline in party membership in the $U K$, terdapat dalam http://www.democraticaudit.com/2015/11/13/fewer-and-olderconsequences-of-the-decline-in-party-membership-in-the-uk/, diakses tanggal 14 April 2019.

Underbow partai masih tumpul, terdapat dalam https://nasional.sindonews.com/read/583640/12/underbow-partai-masih-tumpul$\underline{1330391180}$, diakses tanggal 14 April 2019 